\title{
Gain Enhancement of Applied Micro Patch Antenna in Telemedicine Applications by Changing the Calculation of the Geometry
}

\author{
Fatemeh Lotfi ${ }^{1}$, Hamidreza Shirzadfar, ${ }^{2, *}$, Omidreza Bagheri ${ }^{3}$ \\ ${ }^{1}$ Department of Biomedical Engineering, Faculty of Engineering and Technology, \\ Sheikhbahaee University, Isfahan, Iran \\ 2 Department of Electrical and Biomedical Engineering, Faculty of Engineering and Technology, \\ Shahid Ashrafi Esfahani University, Isfahan, Iran \\ ${ }^{3}$ Department of Mathematics and Statistics, University of Isfahan, Iran
}

(Received 10 January 2021; revised manuscript received 15 April 2021; published online 20 April 2021)

\begin{abstract}
This paper presents an arrangement of a small-scale strip fix getting wire used in a clinical correspondence structure band $(2.45 \mathrm{GHz})$ for Wi-Fi communication. In this assessment, three remarkable thicknesses were used to enhance capability, and, by changing the count of math, we achieved better results. Moreover, different thicknesses of the dielectric substrate were used. The outcomes are presented for three changed thicknesses of $3.175,4$ and $4.808 \mathrm{~mm}$. Radio wire was reproduced using programming and reenactments were performed with no adjustments in math for each of the three thicknesses. The aftereffects of transmission capacity resulted in the most elevated increase of around $8 \mathrm{~dB}$ for a thickness of $4 \mathrm{~mm}$ and furthermore for a thickness of 4.808 with the most noteworthy transfer speed. We streamlined the social event contraption by impelling the assessments. The trade speed stretched out to $170 \mathrm{MHz}$, and the extension reached 8.5276. By utilizing metamaterials, it is conceivable to achieve cut-off of data transmission in a suitable presented radio wire. In addition, the VSWR for all thicknesses is under 2 , which is a tasteful result.
\end{abstract}

Keywords: Telemedicine, Rectangular patch antenna, Microstrip antenna, MRPA, Radio wire.

\section{INTRODUCTION}

Telemedicine suggests really drug delivery [1]. The repeat we used in telemedicine is $2.45 \mathrm{GHz}$, it has three features [2]:

1. There is low repeat block at $2.45 \mathrm{GHz}$.

2. This band is in vain using cash on hand.

3. This repeat is used for Wi-Fi telecommunication.

A radio wire is a critical device remotely between changes. The unmistakable repetitive sets of transmission interchanges are presented in Fig. 1. A cutback scale strip of a square-shaped fix radio wire (MRPA) contains two equivalent driving layers confined by a single dielectric substrate in the most boss structure. The upper driving layer is called a patch and filled in as a radiator. A downsized scale strip radio wire has some regular shapes, for example, rectangular, circular, three-sided or some other shape [3]. In the fundamental structure, a microstrip fix getting wire includes a fixer and a feeder [4].

A more modest scope strip getting wire has a couple of inclinations, which include low profile, lightweight, small size and others, for instance, low increment and low exchange speed. R. Ghatak et al. [5] proposed wideband fractal formed space radio wires for X-band application. An epic fractal planned iris stacked as a dipole cross opening radio wire along sweeping mass of a rectangular waveguide at X-band is organized. To improve the impedance planning, the method for convergence fixing of the cross openings is used. Improvement of the information transfer limit is better than $2 \mathrm{GHz}$ with smoothing of iris significance and taking into account the resulting accentuation space in the location of the essential cross opening. Apex recognized increment remains around $7 \mathrm{~dB}$ over the operational information transfer limit. A model with impedance data transmission better than $2 \mathrm{GHz}(9.6$ to $12 \mathrm{GHz})$ is settled with a resulting cycle of a cross dipole fractal shape-centered opening getting wire stacked with a wound deficient stature iris of $4 \mathrm{~mm}$ thickness and $7.2 \mathrm{~mm}$ significance [6, 7]. Ajay Yadav et al. [8] considered a structure and evaluation of $E$-shape downsized scale strip fix gathering gadget for far away correspondence. The potential benefits of this radio wire were reduced volume, low profile course of action, ease of installation, lightweight, less creation cost. The get-together mechanical gathering goes after $3.1 \mathrm{GHz}$ and $3.45 \mathrm{GHz}$ frequencies. This assembling contraption was executed by utilizing FR4 substrate with dielectric steady of 4.2 and a thickness of $1.6 \mathrm{~mm}$. To overhaul the information transfer limit, two equivalent openings were cut which give additional current way. To accomplish the ideal yield limits, the components of the fix and the ground plane can be similarly changed $[9,10]$. It was noted that the availability of feed centers is directly related to the organized gathering contraption. The arrival loss of -12 and $-28 \mathrm{~dB}$ at working frequencies of 3.1 and $3.45 \mathrm{GHz}$ were independently resolved using this arrangement. In this paper, we expected to show a novel scheme of a rectangular fix radio wire, which is especially used in telemedicine. We reenacted this getting wire and indicated high increment, which is commendable in biomedical repeat (2.45), as well as cultivated reasonable $S$-boundaries $\left(S_{11}\right)$.

\footnotetext{
*hsh@ashrafi.ac.ir

h.shirzadfar@gmail.com
} 


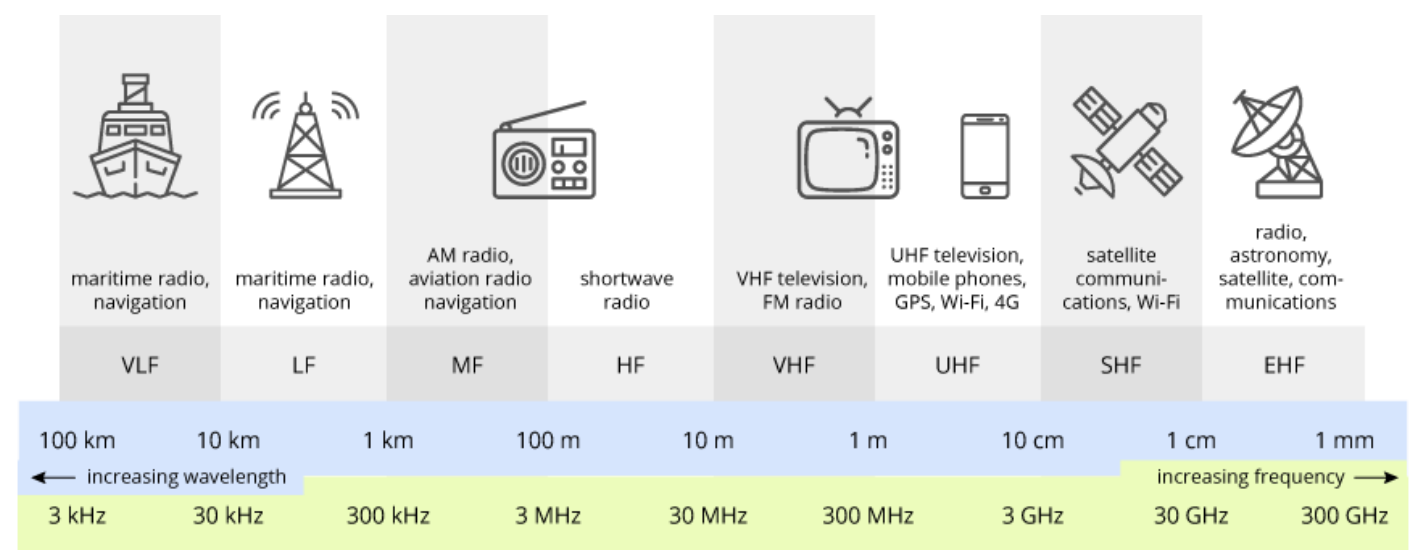

Fig. 1 - The frequency bands of telecommunication [10]

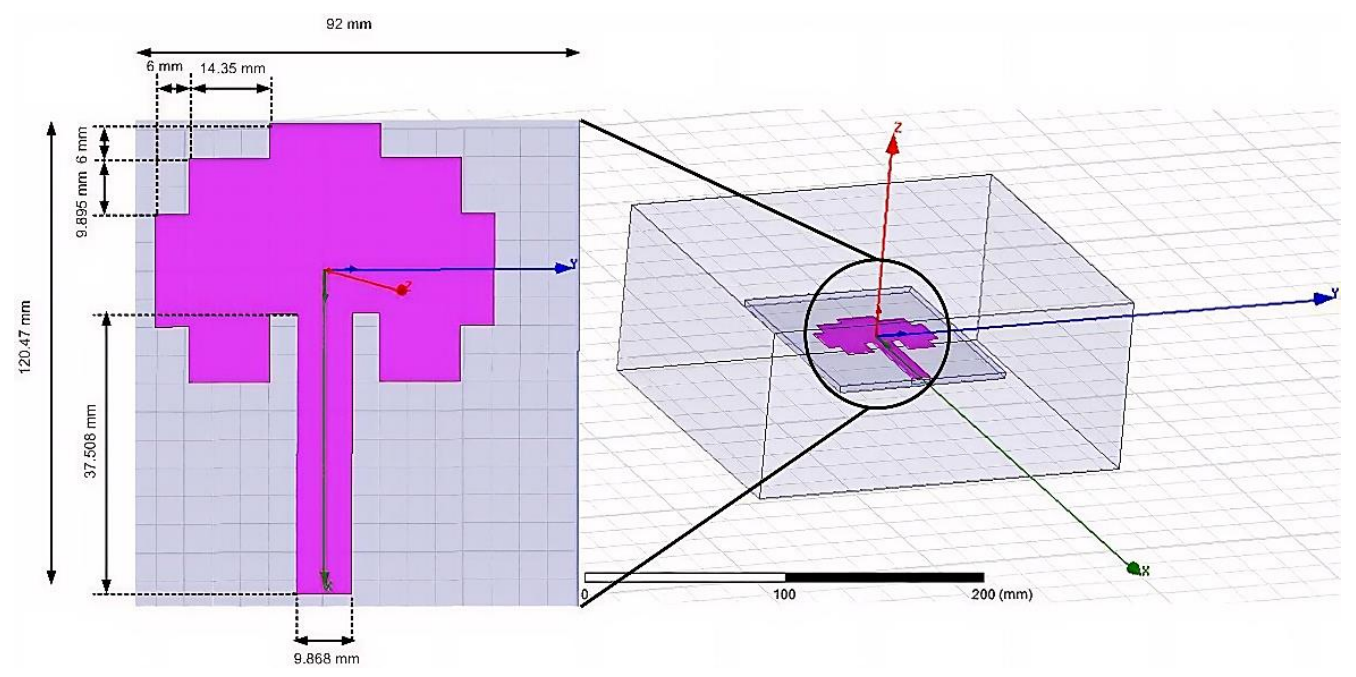

Fig. 2 - Structure of MRPA

\section{LOGICAL INVESTIGATION OF MINIATURIZED SCALE STRIP FIX RADIO WIRE}

A downscaled strip fix gathering device involves two equivalent conductive layers segregated by a dielectric material. The upper conductive layer is called fix and is used for the radiator (see Fig. 1). The lower conductive layer is used for the ground plane. The width and length of the conductive fix should be deflected.

The little scope strip fix gathering contraption plan needs to follow movement of limits: predictable dielectric constant $\left(E_{r}\right)$, full repetition $\left(F_{r}\right)$ and material height $(h)$. Using these limits, the components of the fix can be resolved. Predictable dielectric constant is usually in the range $2.2 \leq E_{r} \leq 12[11,12]$.

The patch width equation is written as [12]:

$$
w=\frac{c}{2 f_{0} \sqrt{\frac{\varepsilon_{r}+1}{2}}} .
$$

The ratio of the speed of light in vacuum is $[13,14]$

$$
\frac{w}{h}>1 \text {. }
$$

A compelling dielectric constant in the range $1<\varepsilon_{e f f}<\varepsilon_{r}$ of the effective dielectric constant of the antenna is obtained from [13]

$$
\varepsilon_{\text {eff }}=\frac{\varepsilon_{r}+1}{2}+\frac{\varepsilon_{r}-1}{2} \sqrt{\frac{1}{1+12^{\frac{h}{w}}}},
$$

where $\varepsilon_{r}$ is the relative permittivity of the substrate used, $h$ is the height of the substrate, $w$ is the width of the patch.

The effective dielectric length of the antenna is calculated by the following equation [15]:

$$
l_{\text {eff }}=\frac{c}{2 f_{r} \sqrt{\varepsilon_{\text {eff }}}} .
$$

The condition for obtaining a longitudinal delta is the following $[16,17]$ :

$$
\Delta l=0.412 h \frac{\left(\varepsilon_{\text {eff }}+0.3\right)\left(\frac{w}{h}+0.264\right)}{\left(\varepsilon_{\text {eff }}-0.258\right)\left(\frac{w}{h}+0.813\right)},
$$

The length relationship is given as [18]:

$$
l=l_{\text {eff }}-2 \Delta l .
$$


Table 1 - Fix getting wire estimations

\begin{tabular}{|c|c|c|}
\hline Index & Parameters & Dimensions \\
\hline$L$ & patch dimension of $\mathrm{x}$ & $39.72 \mathrm{~mm}$ \\
\hline$W$ & patch dimension of $\mathrm{y}$ & $48.63 \mathrm{~mm}$ \\
\hline$X$ & substrate dimension & $120.47 \mathrm{~mm}$ \\
\hline$Y$ & substrate dimension & $92 \mathrm{~mm}$ \\
\hline$X$ & feed dimension & $37.508 \mathrm{~mm}$ \\
\hline$Y$ & feed dimension & $9.868 \mathrm{~mm}$ \\
\hline
\end{tabular}

\section{DESIGN OF MRPA}

For this structure, $\varepsilon_{r}=2.17$ and difficulty deviation $\delta=0.02$ have been utilized. The tolerant wire is replicated with three surprising thicknesses of 3.175, 4 and $4.808 \mathrm{~mm}$ of dielectric material. To accomplish an adequate radio wire, a dielectric material thickness close to low dielectric reliably passes on uncommon yield and extraordinary data transfer limits. There are three models for dismantling the downscaled strip fix radio wire: 1. direct transition model, 2. pit model, and 3. impeccable wave model. To structure this getting wire, the clearest model, practically identical to the prompt model, has been utilized. This model has two layers of patches and the ground plane. Electric field lines are between the ground plane and the fix. A gigantic piece of the electric field lines experiences dielectric matter, and part of it encounters air. Fig. 2 addresses the accepting wire structure. The radio wire assessments of the fix are given in Table 1 . The length $(L)$ and width $(W)$ of the miniature strip fix getting wire are $L=39.72$ and $W=48.63 \mathrm{~mm}$. The fix radio wire is closed when air appears. In this article, we have attempted to redesign capacity by changing the assessments.

\section{SIMULATION RESULTS}

Recreation of the reception apparatus proposed has been completed. The deliberate boundaries incorporate the transfer speed, gain, $S_{11}$ boundary, and VSWR. The outcomes appeared for the three changed thicknesses of $3.175,4$ and $4.808 \mathrm{~mm}$. It is important that this receiving wire was reproduced using programming, and this part was adjusted to improve the computation of the miniature fix, making it more productive than incorporating transmission capacity, gain, $S$ boundary, and VSWR.

Recreations were performed with no adjustment in calculation for each of the three thicknesses. The outcomes are evident in Fig. 3-Fig. 5.

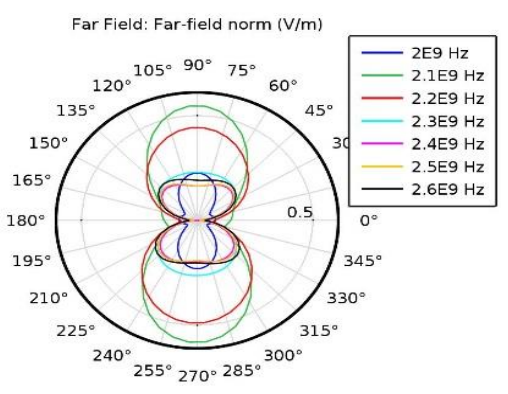

a

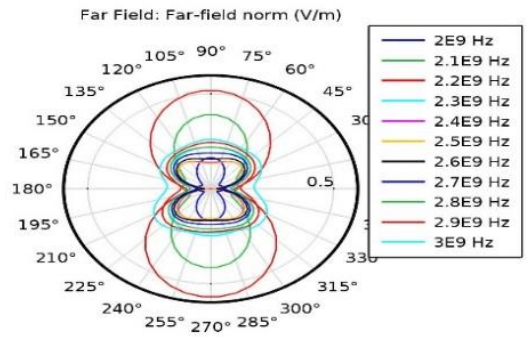

$\mathrm{b}$

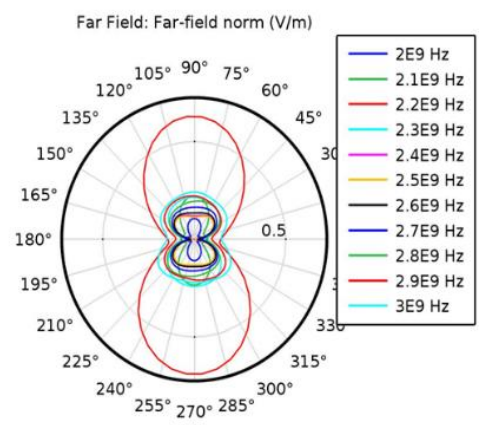

Fig. 3 -Radiation patterns for (a) $3.175 \mathrm{~mm}$, (b) $4 \mathrm{~mm}$ and (c) $4.808 \mathrm{~mm}$
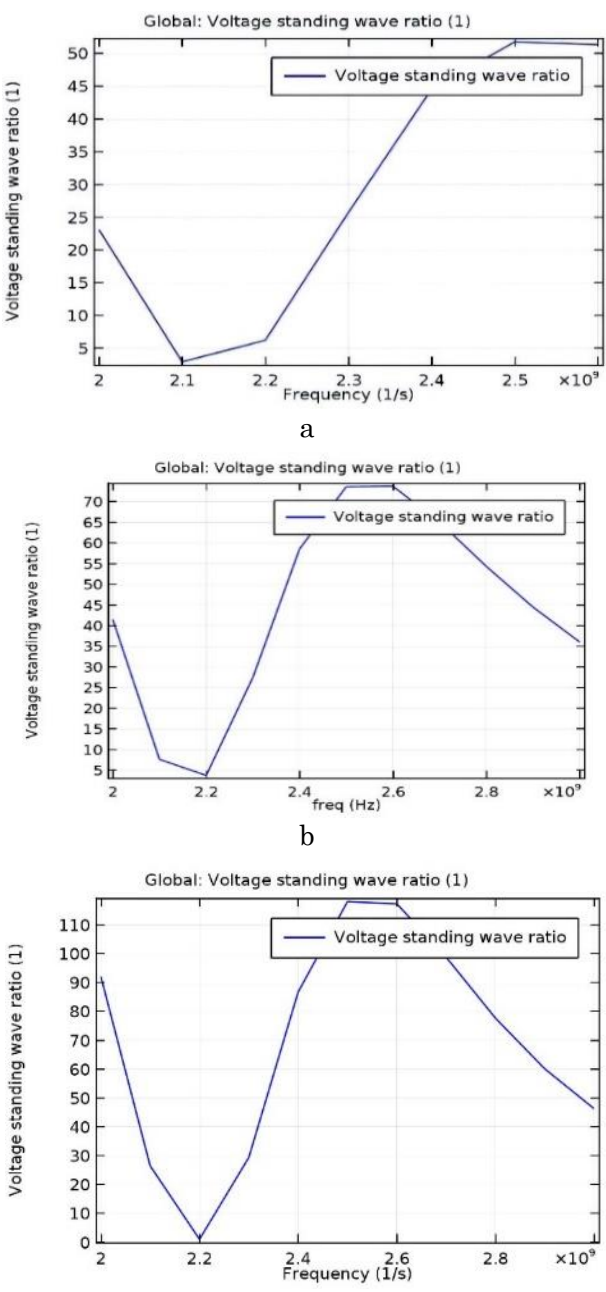

c

Fig. 3 - VSWR for (a) $3.175 \mathrm{~mm}$, (b) $4 \mathrm{~mm}$, (c) $4.808 \mathrm{~mm}$ 
The results of transmission capacity, gain and $S_{11}$ boundaries are given for each of the three thicknesses in Table 2 leading to the most notable addition of around $8 \mathrm{~dB}$ for a thickness of $4 \mathrm{~mm}$ and furthermore for a thickness of $4.808 \mathrm{~mm}$ with the most noteworthy data transfer capacity.

Table 2 - Results of simulation

\begin{tabular}{|c|c|c|c|c|}
\hline Index & $\begin{array}{c}\text { Substrate } \\
\text { thickness }\end{array}$ & Gain & Bandwidth & VSWR \\
\hline$H 1$ & $3.175 \mathrm{~mm}$ & $8.1473 \mathrm{~dB}$ & $100 \mathrm{MHz}$ & $\begin{array}{c}1.2 \\
(\text { at } 2.1 \mathrm{GHz})\end{array}$ \\
\hline$H 2$ & $4 \mathrm{~mm}$ & $8.3574 \mathrm{~dB}$ & $100 \mathrm{MHz}$ & $\begin{array}{c}1.1 \\
(\text { at } 2.2 \mathrm{GHz})\end{array}$ \\
\hline$H 3$ & $4.808 \mathrm{~mm}$ & $7.7545 \mathrm{~dB}$ & $140 \mathrm{MHz}$ & $\begin{array}{c}1.2 \\
(\text { at } 2.2 \mathrm{GHz})\end{array}$ \\
\hline
\end{tabular}

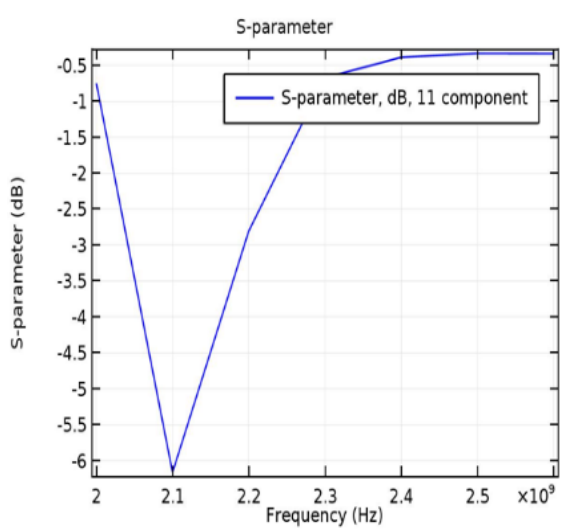

a

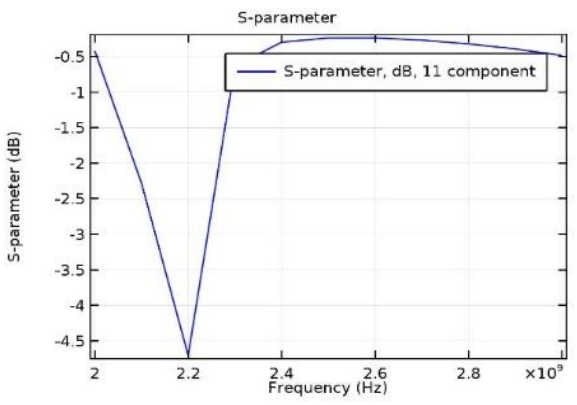

b

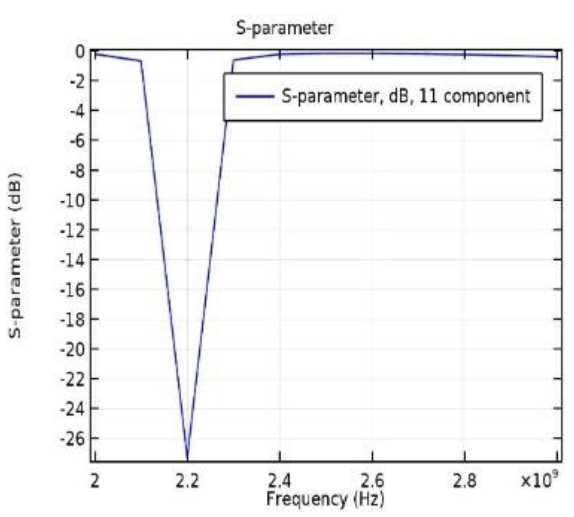

$\mathrm{c}$

Fig. 5 - The $S_{11}$ parameter for (a) $3.175 \mathrm{~mm}$, (b) $4.000 \mathrm{~mm}$ and (c) $4.808 \mathrm{~mm}$

The following results are obtained by optimizing the dimensions (Fig. 6). See also the optimized simulation results in Table 3. As seen, the bandwidth and gain have become more optimized.
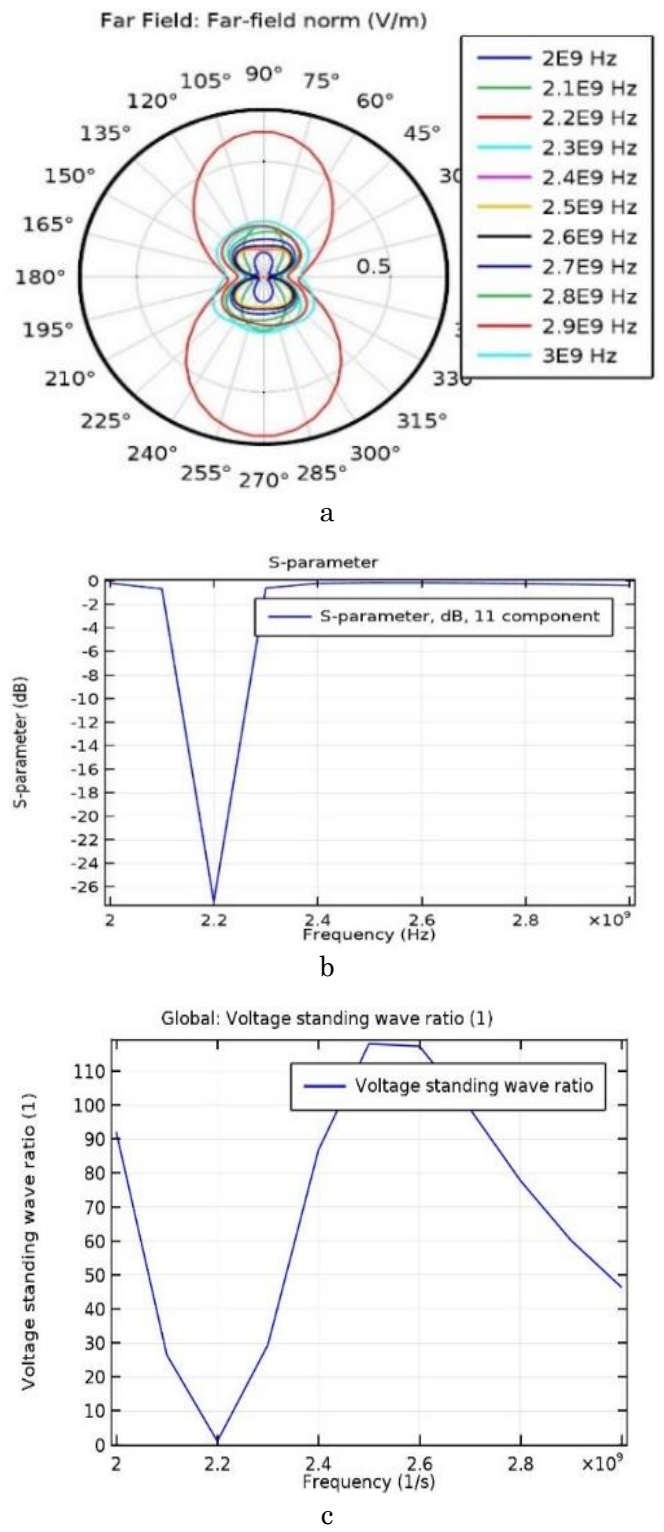

Fig. 6 - (a) Radiation pattern for $3.175 \mathrm{~mm}$, (b) VSWR for $3.175 \mathrm{~mm}$, (c) $S_{11}$ parameter for $3.175 \mathrm{~mm}$

Table 3 - Aftereffects of recreation

\begin{tabular}{|c|c|c|c|}
\hline $\begin{array}{c}\text { Substrate } \\
\text { thickness }\end{array}$ & Gain & Bandwidth & VSWR \\
\hline$H 1=3.175 \mathrm{~mm}$ & $8.5276 \mathrm{~dB}$ & $170 \mathrm{MHz}$ & 1.0350 \\
\hline
\end{tabular}

\section{CONCLUSIONS}

A small-scale strip radio wire used in telemedicine has been considered. The best extension outcome is accomplished at a thickness of $4 \mathrm{~mm}$, and its preferred position for the most part is $8.36 \mathrm{~dB}$. Likewise, the outcomes indicate that a radio wire with $4.808 \mathrm{~mm}$ thickness has an extra data transmission equal to $140 \mathrm{MHz}$. As shown in Fig. 4, as far as possible, a return effect of no more than $-10 \mathrm{~dB}$ is quite acceptable for bandwidth selection. The best results of $S$ limits are found for a fix radio wire with $4.808 \mathrm{~mm}$ thickness. The obtained re- 
sults of VSWR are shown. All the holes are some spots of 1 and $2 \mathrm{~dB}$. VSWR is recommended as the ratio of the phenomenal to the lowest voltage which is assessed by COMSOL programming and divided between three substrate thicknesses $H 1=3.175 \mathrm{~mm}, H 2=4 \mathrm{~mm}$ and $H 3=4.808 \mathrm{~mm}$. At long last, we streamlined the social affair contraption by driving the assessments. As should be clear from Table 3, the trade speed reached $170 \mathrm{MHz}$, and the expansion extended to 8.5276. By utilizing metamaterials, it is conceivable to develop the data transfer breaking point of the proposed radio wire. In our future work, we intend to update data transmission on the accepting wire, which is more usable in telemedicine.

\title{
REFERENCES
}

1. B. Fong, A.C.M. Fong, C.K. Li, Telemedicine Technologies (John Wiley \& Sons) (2011).

2. C.S. Pattichis, E. Kyriacou, S. Voskarides, M.S. Pattichis, R. Istepanian, C.N. Schizas, IEEE Anten. Propag. Magaz. 44 No 2, 143 (2002).

3. C. Hoving, A. Visser P. Dolan Mullen, Bart van den Borne, Pat. Educ. Counsel. 78 No 3, 275 (2010).

4. E.W. Ferguson, C.R. Doarn, J.C. Scott, J. Med. System. 19 No 1, 35 (1995).

5. S.W. Strode, S. Gustke, A. Allen, JAMA 281 No 12, 1066 (1999).

6. R. Wootton, J. Craig, V. Patterson, Introduction to Telemedicine (CRC Press: London: 2017).

7. A.K. Jha, J.B. Perlin, K.W. Kizer, R.A. Dudley, New England J. Med. 348 No 22, 2218 (2003).

8. V.K. Singh, A. Kumar, Int. Res. J. Eng. Techn. 3 No 7, 1312 (2016).

9. D.M. Pozar, Proc. IEEE 80 No 1, 79 (1992).

10. T. Huynh, K.F. Lee, Electr. Lett. 31 No 16, 1310 (1995).

11. H. Shirzadfar, F. Lotfi, Int J. Biosens. Bioelectron 3 No 4, 303 (2017).

12. H. Shirzadfar, P. Shirvani, J. Bioanal. Biomed. 8 No 5, 1000e145 (2016).

13. P. Shirvani, H. Shirzadfar, J. Nano-Electron. Phys. 8 No 3, 03028 (2016).

14. P. Shiryani, H. Shirzadfar, J. Nano- Electron. Phys. 12 No 5 , 05034 (2020).

15. R.A. Valdez, N. Wongkasem, 2019 IEEE Int. Symp. on Ant. and Prop. and USNC-URSI Radio Scien. Meeting (2019).

16. S.R. Bhongale, P.N. Vasambekar, Int. J. Sci. Res. 4 No 10, 48 (2015).

17. http://www.britannica.com/topic/telecommunication

\section{Збільшення підсилення прикладної мікро-патч-антени у додатках телемедицини шляхом зміни розрахунку геометрії}

\author{
Fatemeh Lotfi ${ }^{1}$, Hamidreza Shirzadfar ${ }^{2}$, Omidreza Bagheri ${ }^{3}$ \\ ${ }^{1}$ Department of Biomedical Engineering, Faculty of Engineering and Technology, \\ Sheikhbahaee University, Isfahan, Iran \\ 2 Department of Electrical and Biomedical Engineering, Faculty of Engineering and Technology, \\ Shahid Ashrafi Esfahani University, Isfahan, Iran \\ ${ }^{3}$ Department of Mathematics and Statistics, University of Isfahan, Iran
}

\begin{abstract}
У роботі представлено конструкцію невеликого кабелю, який використовуеться в структурній смузі медичного листування (2,45 ГГц) для зв'язку Wi-Fi. Було використано три товщини для розширення можливостей i, змінивши математичні розрахунки, ми досягли кращих результатів. Більше того, застосовувалися різні товщини діелектричної підкладки. Результати були отримані для трьох товщин 3,175, 4 та 4,808 мм. Радіодріт було відтворено за допомогою програмування, і відтворення проводились без жодних математичних коригувань для кожної з трьох товщин. Результати показують, що пропускна здатність максимально збільшилася приблизно на 8 дБ при товщині 4 мм, а при товщині 4,808 мм спостерігалася найвизначніша швидкість передачі. Ми оптимізували конструкцію, провівши оцінювання. Швидкість передачі зросла до 170 МГц, а розширення досягло 8,5276. Використовуючи метаматеріали, можна досягти переривання передачі даних у потрібному радіодроті. Крім того, коефіцієнт питомого поглинання для всіх товщин становить менше 2 , що є відмінним результатом.
\end{abstract}

Ключові слова: Телемедицина, Прямокутна патч-антена, Мікросмугова антена, MRPA, Радіодріт. 